\title{
Infection of Human T Lymphotropic Virus-I-specific Immune T Cell Clones by Human T Lymphotropic Virus-I
}

\author{
Hiroaki Mitsuya, * Ruth F. Jarrett, $\neq$ Jeffrey Cossman,\$ Oren J. Cohen," Chien-Song Kao,II \\ Hong-Guang Guo, $\neq$ Marvin S. Reltz, $\neq$ and Samuel Broder* \\ The Clinical Oncology Program,* Laboratory of Tumor Cell Biology, $\ddagger$ Laboratory of Pathology, $\S$ \\ Medicine Branch, National Cancer Institute, Bethesda, Maryland 20892
}

\begin{abstract}
Human T lymphotropic virus-I (HTLV-I)-specific T cell lines were established and cloned. K5, an $\mathrm{OKT8}^{+}$clone bearing multiple proviral integration sites, retained its HTLV-I-specific cytotoxicity and a normal dependence on interleukin 2 (IL-2), indicating that there is a finite number of transforming integration sites. R2, an OKT4+ HTLV-I-infected clone, initially mounted a proliferative response to HTLV-I; but then its IL-2-independent proliferation increased and the antigen specificity was lost. All HTLV-I-infected clones tested including K7, another OKT8 ${ }^{+}$ transformed cytotoxic clone that had lost its reactivity, expressed comparable levels of $T$ cell receptor $\beta$-chain (TCR- $\beta$ ) messenger (m)RNA. Although clones $\mathrm{K5}$ and $\mathrm{K} 7$ had different functional properties, they had the same rearrangement of the TCR- $\beta$ gene, suggesting that they had the same clonal origin.

These data indicate that HTLV-I-specific T cells retain their immune reactivity for variable periods of time following infection, but then usually lose it; in some cases, however, no alteration in function can be detected. The data also suggest that different consequences can take place in the same clone depending on the pattern of retroviral infection.
\end{abstract}

\section{Introduction}

Pathogenic retroviruses are now known to be important causes of diseases in human beings. Such viruses play a vital role in the pathogenesis of certain adult $T$ cell neoplasms (1-4), and one pathogenic human retrovirus, human $T$ lymphotropic virus typeIII (HTLV-III) ${ }^{1}(5,6)$, also called lymphadenopathy-associated virus (7) or acquired immunodeficiency syndrome-related virus (8), has recently been shown to be the causative agent of acquired immune deficiency syndrome. The $\mathrm{T}$ cell neoplasm associated with the first known pathogenic retrovirus, HTLV-I, carries an exceedingly grave prognosis attributable to the malignancy itself,

Address reprint requests to Dr. Mitsuya, 13N248, Building 10, Clinical Oncology Program, National Cancer Institute, Bethesda, MD 20892.

Received for publication 16 September 1985 and in revised form 16 June 1986.

1. Abbreviations used in this paper: $\mathrm{C} \beta 1, \mathrm{C} \beta 2,5^{\prime}$ and $3^{\prime}$ genes, respectively, for the constant region of the T cell receptor $\beta$-chain; EBV, Epstein-Barr virus; E/T, effector/target ratio; FACS, fluorescence-activated cell sorter, FCS, fetal calf serum; HTLV, human T-lymphotropic virus; IL-2, interleukin 2; MJ-B, EBV-transformed B cells from patient MJ; MJ-CTL, long-term cultured cytotoxic $T$ cell line from patient MJ; PBM, peripheral blood mononuclear cells; PHA, phytohemagglutinin; TCR- $\beta$, T cell receptor $\beta$-chain.

The Journal of Clinical Investigation, Inc.

Volume 78, November 1986, 1302-1310 life-threatening hypercalcemia, or an unexplained susceptibility to infection with Pneumocystis carinii and other pathogens (4, 9-12). In southwestern Japan and in the West Indies, infection with HTLV-I is an endemic phenomenon, which in certain cases is associated with the development of a fulminant kind of $T$ cell leukemia or lymphoma, often comprised of neoplastic cells with suppressor function and OKT4 phenotype $(4,13)$. Other regions of the world where HTLV-I is endemic include the southeastern United States, substantial portions of Africa, and parts of South America.

A well-recognized property of HTLV-I is the ability to infect and transform $\mathrm{T}$ cells from normal umbilical cord blood, bone marrow, and sometimes antigen-specific $\mathrm{T}$ cells in vitro (1418). However, the interactions among a transforming human retrovirus and $T$ cells that have specific reactivity for the virus have not been studied extensively, and relatively little is known about the consequences of HTLV-I infection on the virus-specific immune response in patients infected with this agent. Recently, we and others generated long-term immune $T$ cell lines from patients with HTLV-I-associated T cell neoplasms (19-21). The immune $\mathrm{T}$ cells can mediate HLA-antigen restricted, cytotoxic and proliferative responses against HTLV-I-infected target cells. While a partial analysis of the specificity of the $T$ cell response to HTLV-I was possible, a more definitive analysis at the biologic and molecular level is best done with cloned $\mathrm{T}$ cell lines. In particular, such cloned $\mathrm{T}$ cells provide a broader opportunity to examine the functional consequences of HTLV-I infection and replication in cells with specific immune reactivity against this agent.

In this paper, we report that HTLV-I-specific immune T cell clones mediate immune responses for a variable period after infection with HTLV-I; however some clones transformed by the virus eventually lose their specific immune reactivity. We also show that all HTLV-I-infected clones tested, whether they retained or lost immune reactivity, had a clonally rearranged gene encoding the $T$ cell receptor $\beta$-chain (TCR- $\beta$ ), and expressed comparable levels of TCR- $\beta$ messenger RNA (mRNA). Furthermore, we report a similar TCR- $\beta$ gene configuration in two functionally different HTLV-I-infected clones, one of which contains two integrated proviruses, and the second contains multiple proviruses apparently integrated at random. We conclude that there is a spectrum of functional consequences of HTLV-I infection in immune $T$ cell clones that are reactive against this virus.

\section{Methods}

The patient. $\mathrm{T}$ cell clones in this study were derived from the peripheral blood cells of patient M.J., a 53-yr-old White male with circulating antibodies against internal structural proteins of HTLV-I. In 1977, he was diagnosed as having cutaneous $\mathrm{T}$ cell lymphoma, and he eventually be- 
came a complete responder to a regimen of chemotherapy, whole-body electron beam irradiation, and topical nitrogen mustard. The patient's disease was in clinical remission when these studies were initiated in January 1983.

Target and stimulator cells for T cell reactivity. MJ-tumor is an HTLVI-producing neoplastic $\mathrm{T}$ cell line (with a $17 \mathrm{q}+$ karyotypic marker) that was derived from peripheral blood of the patient MJ (15). MJ-tumor cells replicate in the absence of IL-2 (or T cell growth factor). HUT-102B2 and WA-tumor are HTLV-I-producing neoplastic T cell lines derived from C.R. and W.A., patients who had HTLV-I-associated neoplasms (15). C145/TK is a cord blood T cell line transformed by HTLV-I (15). Phytohemagglutinin (PHA)-induced T cell blasts from patient M.J. in remission were also used. In PHA-induced T cell blasts, HTLV-I gag proteins were not detected as assessed by indirect immunofluorescence assay. Other cell lines used included an erythroid line K562 as well as Epstein-Barr virus (EBV)-transformed B cells from patient M.J. (MJ-B).

Establishment of $T$ cell clones reactive against HTLV-I. Long-term immune $\mathrm{T}$ cell lines reactive against HTLV-I were generated on four separate occasions. The establishment of the $T$ cell line was previously described (19). Briefly, $10^{7}$ peripheral blood mononuclear cells (PBM) separated from heparinized blood from patient $\mathrm{MJ}$ were co-cultured with $10^{6}$ irradiated (12,000 rad) MJ-tumor cells in RPMI 1640 supplemented with $10 \%$ heat-inactivated human $\mathrm{AB}$ serum, $4 \mathrm{mM}$ L-glutamine, $5 \times 10^{-5} \mathrm{M}$ 2-mercaptoethanol, $50 \mathrm{U} / \mathrm{ml}$ penicillin, and $100 \mu \mathrm{g} / \mathrm{ml}$ streptomycin. On day 6 and beyond, these cells were continuously exposed to 20\% IL-2 (vol/vol) (lectin-depleted; Cellular Products, Inc., Buffalo, NY) containing RPMI 1640 with $10 \%$ heat-inactivated fetal calf serum (FCS) (Gibco Laboratories, Grand Island, NY) without further use of human serum. The culture was repeatedly stimulated with irradiated MJ-tumor cells at 7-14-d intervals. After $>30 \mathrm{~d}$ in culture, the longterm cultured $\mathrm{T}$ cell lines (MJ-CTL) were cloned by limiting dilution. 0.1 -ml aliquots containing $20,5,1$, or 0.5 cells in $20 \%$ IL-2-containing media were distributed into round-bottomed, 96-well microtiter plates (Linbro Chemical Co., Hamden, CT) with $10^{4}$ irradiated $(12,000 \mathrm{rad})$ MJ-tumor cells and $10^{4}$ irradiated (4,000 rad) autologous PBM harvested from patient M.J. in remission. The plates were incubated at $37^{\circ} \mathrm{C}$ in $5 \% \mathrm{CO}_{2}$-containing humidified air and fed with $20 \% \mathrm{IL}-2$ in $0.1 \mathrm{ml}$ media every 4-5 d. Growing colonies were identified on days 10-30, transferred to 24-well plates (Costar Data Packaging, Cambridge, MA) and fed with media containing $20 \%$ IL-2 without further addition of irradiated MJ-tumor cells. Clones were expanded from the positive wells that were plated with 0.5 cells per well. One clone (R2) from this initial cloning was recloned using the same technique but in the absence of HTLV-I-producing MJ-tumor cells. Subclones obtained were expanded from the positive wells plated with 0.5 cells per well.

${ }^{51}$ Cr-release assays. A 4-h ${ }^{51} \mathrm{Cr}$-release assay was carried out as previously described (19). Briefly, thoroughly washed target cells were labeled with $0.1-0.2 \mathrm{ml}$ of $\mathrm{Na}_{2}{ }^{51} \mathrm{CrO}_{4}(1 \mathrm{mCi} / \mathrm{ml}$, sp act $250-500 \mu \mathrm{Ci} / \mathrm{mg}$; Amersham Corp., Arlington Heights, IL) in a $37^{\circ} \mathrm{C}$ bath for $30-60 \mathrm{~min}$ with periodic shaking. The cells were then washed at least four times in media, counted, and dispersed in round-bottomed microtiter plates at $10^{4}$ cells per well in $0.05 \mathrm{ml}$ of $4 \%$ FCS-containing RPMI 1640 . Effector cells at desired concentrations were added in three to five replicates at different effector/target $(\mathrm{E} / \mathrm{T})$ ratios in $0.1 \mathrm{ml}$ of the media. After the plates were incubated at $37^{\circ} \mathrm{C}$ for $4 \mathrm{~h}$ and centrifuged for $3 \mathrm{~min}$, the supernatants were collected with the Titertek supernatant collection system (Flow Laboratories Ltd., Irvine, CA). The percent specific ${ }^{51} \mathrm{Cr}$-release was determined by the following formula: $100 \times$ (release in test - spontaneous release)/(maximum release - spontaneous release). Tests in which spontaneous release exceeded $30 \%$ were disregarded.

Antigen-driven proliferative assays. $10^{5}$ washed responder cells were cultured for $3 \mathrm{~d}$ with various numbers of irradiated $(12,000 \mathrm{rad})$ stimulator cells in the absence of exogenous IL-2 in $200 \mu \mathrm{l}$ of $10 \%$ FCS-containing supplemented RPMI 1640 at $37^{\circ} \mathrm{C}$ in $5 \% \mathrm{CO}_{2}$-containing humidified air. All cultured cells were pulsed for $5 \mathrm{~h}$ with $0.5 \mu \mathrm{Ci}$ of $\left[{ }^{3} \mathrm{H}\right]$ thymidine, harvested onto glass fibers, and assessed for the incorporation of isotope as an indicator of proliferation in response to antigen. The results are expressed as the arithmetic mean counts per minute \pm 1 standard deviation for triplicate cultures.

Analysis of surface antigens by monoclonal antibodies. Phenotypic analysis was performed by using indirect immunofluorescence on a fluorescence-activated cell sorter (FACS II, Becton-Dickinson, Co., Sunnyvale, CA), as previously described (22). Briefly, cells were incubated with monoclonal antibodies concentrated at 50-200 ng of antibody to $2 \times 10^{5}$ cells. The cells were then washed and treated with an affinitypurified fluorescein-conjugated IgG fraction of goat anti-mouse IgG (whole molecule) (Sigma Chemical Co., St. Louis, MO). Control staining with nonreactive mouse ascites at the equivalent protein concentration was consistently negative. The cells were tested with the following antibodies; OKT3, OKT4, OKT8 (Ortho Pharmaceuticals, Raritan, NJ), HLA-DR (Becton-Dickinson), and anti-Tac (23), a monoclonal antibody that reacts with an epitope identical or closely linked to the cellular receptor for IL-2 (24).

Chromosomal analysis. Chromosomal analysis of the cultured cells was performed by using direct, air-dried chromosomal preparations as previously described (25). Cells were incubated, harvested, and stained with conventional Giemsa or were G-banded using trypsin-Giemsa. Metaphases were scored for aberrations, and karyotypes were prepared according to the Paris Conference.

Detection of HTLV-I-encoded antigens. Expression of HTLV-I gag proteins, $\mathrm{p} 19$ and $\mathrm{p} 24$, in $\mathrm{T}$ cells was determined by an indirect immune fluorescence assay on methanol:acetone-fixed cells using a murine monoclonal antibody to HTLV-I p19 and a goat polyclonal antibody specific for purified HTLV-I p24. Fluoresence isothiocyanate-labeled goat anti-mouse $\operatorname{IgG} F\left(a b^{\prime}\right)_{2}$ and swine anti-goat IgG were used to detect reactive cells as previously described $(26,27)$.

Nucleic acid analyses. High molecular weight DNA was digested with pronase-sodium dodecyl sulfate (SDS) and extracted with organic solvents as previously described $(28,29)$. For Southern blots, 20-30 $\mu \mathrm{g}$ of DNA were digested for $16 \mathrm{~h}$ at $37^{\circ} \mathrm{C}$ with $60 \mathrm{U}$ of the indicated restriction endonucleases purchased from Boehringer-Mannheim, Indianapolis, IN or International Biotechnologies, New Haven, CT, using the conditions specified by the manufacturers. These digests were subjected to electrophoresis overnight at $40 \mathrm{~V}$ in $0.8 \%$ agarose, transferred to nitrocellulose, and hybridized. The HTLV-I probe consisted of a ${ }^{32} \mathrm{P}$ nick translated DNA insert from a subclone (pCH-I) in pBR-322 of the portions of the HTLV-I genome defined by the Cla I and Hind III sites of $\lambda C R-1$ (30) and containing pol-env-pX sequences. The TCR- $\beta$ probe was an insert excised with Pst I from a cDNA clone in pBR-322 of TCR$\beta$ mRNA from the Jurkat cell line, generously provided by Dr. T. $W$. Mak (31). Hybrid bands were detected by autoradiography with Kodak AR film (Eastman Kodak Co., Rochester, NY) in a cassette using a Dupont Quanta III screen (E. I. Dupont de Nemours, Wilmington, DE).

Dot blot hybridizations to measure mRNA levels were performed as previously described (32).

\section{Results}

Generation and cloning of HTLV-I-specific immune T cells (MJ$C T L$ ). Long-term cultured IL-2-dependent T cell lines (MJCTL) were established from the patient on four separate occasions. These cultured T lymphocytes killed HTLV-I-infected target cells that shared at least HLA-Al with patient MJ (33), but did not kill other HLA-incompatible HTLV-I-infected T cell lines, autologous EBV-transformed B cells (MJ-B), K562 cells, or autologous PHA-activated blast cells from the patient after the neoplasm was in remission (Fig. 1 and Table I). WAtumor cells which shared HLA-A1, -B8, -Cw7, and -DR3 with MJ-tumor were killed less well than MJ-tumor cells. In a representative experiment, at an E/T ratio of 10:1, MJ-CTL killed $56.3 \%$ of MJ-tumor cells, whereas it killed $30.7 \%$ of WA-tumor cells and $32.3 \%$ of C145/TK (that shared only HLA-A1 with MJ-tumor). MJ-tumor has the capacity to produce a high num- 


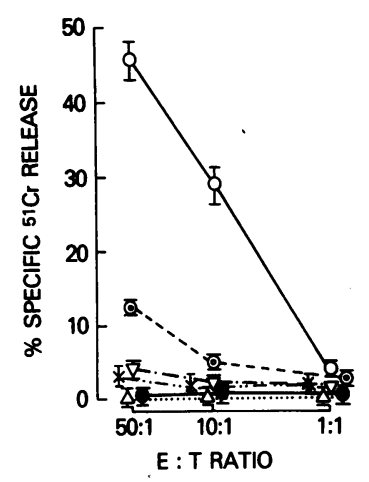

Figure 1. Cytotoxicity of the starting uncloned immune $\mathrm{T}$ cell line (MJCTL) reactive with HTLV-I-bearing, HLA-matched cultured tumor cells. MJ-CTL was tested on day 83 in culture. Target cells: MJ-tumor (0), WAtumor (๑), HUT-102-B2 ( $\triangle$ ), MJ-B (๑), MJ-PHA blast $(X)$, and K562 $(\nabla)$ cells. Each symbol represents the mean percent specific ${ }^{51} \mathrm{Cr}$-release \pm 1 SD of triplicate determinations. Note that MJCTL killed MJ-tumor cells and WAtumor cells that shared HLA-A1, -B8, $-\mathrm{Cw} 7$, and -DR3.

ber of infectious virions and to immortalize $T$ cells upon coculture in vitro, but WA-tumor does not have that capacity (unpublished). The level of expression of virus-associated protein in HTLV-I-bearing tumor cells may be thus responsible for the difference in the susceptibility to the cytotoxicity of MJ-CTL. It is also possible that there are multiple virus-HLA restricting elements in bulk MJ-CTL.

We attempted to clone this MJ-CTL line in the presence of irradiated HTLV-I-bearing autologous tumor (MJ-tumor) cells and irradiated autologous PBM. The cloning efficiency was $\sim 1$ in 50 as detected by Poisson analysis of large numbers of replicate microcultures set up with varying numbers of MJ-CTL cells. 14 of 19 clones that arose from wells seeded with 0.5 cells were cytotoxic against MJ-tumor cells. We studied four clones (C5, $\mathrm{K} 5, \mathrm{~K} 7$, and R2) in detail. As determined by FACS analysis, clones $\mathrm{C} 5, \mathrm{~K} 5$, and $\mathrm{K} 7$ reacted with OKT3 and OKT8 antibodies, while clone $\mathrm{R} 2$ was positive for OKT3 and OKT4. The majority of the cells were $\mathrm{Tac}^{+}$and HLA-DR ${ }^{+}$. A summary of the properties of these clones is provided in Table $\mathrm{I}$.

HTLV-I-specific cytotoxic clones. Clones $\mathrm{C} 5, \mathrm{~K} 5$, and $\mathrm{K} 7$ expressed the phenotypes of mature suppressor/killer T-cells and clearly recognized HTLV-I in the context of HLA. These clones mediated a substantial level of cytotoxicity for MJ-tumor and WA-tumor cells, but did not kill HUT-102-B2, PHA-induced $\mathrm{T}$ cell blasts from the patient in remission, autologous EBVtransformed B-cells (MJ-B), or K562 at various E/T cell ratios. Representative data are provided in Table I. In the competitive cold target inhibition test, the cytolytic activity of these three clones was selectively blocked by the addition of unlabeled MJ- tumor cells but not by any other unlabeled HLA-incompatible HTLV-I-bearing cells tested (data not shown). Clones C5 and K5 failed to proliferate in response to irradiated MJ-tumor cells. These clones continued to grow for $\sim 3$ mo after cloning, then stopped replication, exhibiting the "growth crisis" that is a common feature of normal IL-2-dependent $T$ cells. These clones exhibited full cytotoxic activity until growth stopped. In the case of clones $\mathrm{C5}$ and $\mathrm{K} 5$, it is thus difficult to discern the functional consequences of HTLV-I infection. On the other hand, clone $\mathrm{K} 7$ could proliferate in the absence of added antigen or IL-2, although its rate of replication was increased by exogenously added IL-2. The spontaneous replication of clone $\mathrm{K} 7$ was profoundly inhibited upon exposure to autologous HTLV-I-bearing MJ-tumor cells and this clone progressively lost cytotoxic activity with time in culture (29).

An $H T L V$-I-specific proliferative clone, $R 2$. The OKT $4^{+}$ clone $\mathbf{R} 2$ did not show any cytotoxic activity against MJ-tumor cells (Table I), but did mount a substantial proliferative reaction in response to irradiated MJ-tumor cells in a dose dependent fashion in the absence of exogenously added IL-2 (Fig. $2 \mathrm{~A}$ ). This clone failed to proliferate when exposed to autologous EBVtransformed B cells (MJ-B) or HLA-unmatched HTLV-I-bearing cells such as HUT-102-B2. However, the spontaneous proliferative rate of clone $\mathrm{R} 2$ increased with time in culture, and concurrently the response to MJ-tumor cells decreased gradually between days 23 and 52 (Fig. 2, $B$ and $C$ ). An HTLV-I-specific response was not detected on day 70 and beyond after cloning. When clone $\mathbf{R} 2$ was recloned at this point, it was not possible to restore the proliferative capacity to HTLV-I. The T cell differentiation-antigen profile (Table I) was unchanged for $>300$ $\mathrm{d}$ in culture. Cytogenetic analysis showed that ten of ten of the clone $\mathbf{R} 2$ cells analyzed had a reciprocal translocation between chromosomes 7 and $9(46, X Y, \operatorname{rcp}(7 ; 9)(\mathrm{p} 12 ; \mathrm{q} 31))$, providing an independent indication of a monoclonal origin for the R2 cell population.

Infection of HTLV-I-specific T-cell clones with HTLV-I. Since the starting uncloned line MJ-CTL as well as the four clones had been exposed to repeated cycles of stimulation with autologous HTLV-I-bearing tumor (MJ-tumor) cells, we asked whether these cells were infected with HTLV-I. Southern blot hybridization of MJ-CTL DNA following digestion with Eco RI (which does not cut within proviral DNA, making the presence of one band an indicator of a unique viral integration site) and labeling with an HTLV-I probe (pCH-I) containing pol-env-pX

Table I. Cytotoxicity and Surface Phenotypes of Clones

\begin{tabular}{|c|c|c|c|c|c|c|c|c|c|c|c|c|}
\hline \multirow[b]{2}{*}{ Clones } & \multicolumn{7}{|l|}{ Targets* } & \multicolumn{5}{|c|}{ Phenotypesł } \\
\hline & MJ-tumor & WA-tumorß & C145/TK§ & HUT-102 B2 & MJ-PHA & MJ-B & K562 & OKT3 & OKT4 & OKT8 & Tac & HLA-DR \\
\hline C5 & 67 & 36 & ND & 1 & 1 & 1 & 6 & 98 & $<2$ & 98 & ND & ND \\
\hline K5 & 65 & 33 & 34 & 4 & -5 & 3 & 2 & 97 & $<1$ & 95 & 70 & 92 \\
\hline $\mathbf{K} 7$ & 80 & 41 & 36 & 5 & -5 & 2 & 3 & 98 & $<3$ & 84 & 92 & 92 \\
\hline $\mathbf{R} 2$ & 6 & -1 & -3 & -4 & -1 & 1 & -2 & 95 & 96 & $<2$ & 95 & 96 \\
\hline MJ-CTL" & 56 & 31 & 32 & 3 & -5 & 4 & 4 & 97 & $<3$ & 93 & 75 & 97 \\
\hline MJ-tumor & - & - & - & - & - & - & - & 18 & 68 & $<2$ & 81 & 79 \\
\hline
\end{tabular}

ND, not determined. * Each number denotes the mean percentage of specific ${ }^{51} \mathrm{Cr}$-release done in triplicate at an E:T ratio of 10:1. $¥$ Assessed by indirect immunofluorescence using FACS. All clones were tested within $30 \mathrm{~d}$ after cloning. Data are expressed as percentages of positive cells. $\S$ WA-tumor shares HLA-A1, -B8, -Cw7, and -DR3, while C145/TK shares only HLA-A1 with MJ-tumor. "The uncloned MJ-CTL line (tested on day 106 in culture) and MJ-tumor cells are shown for reference. 


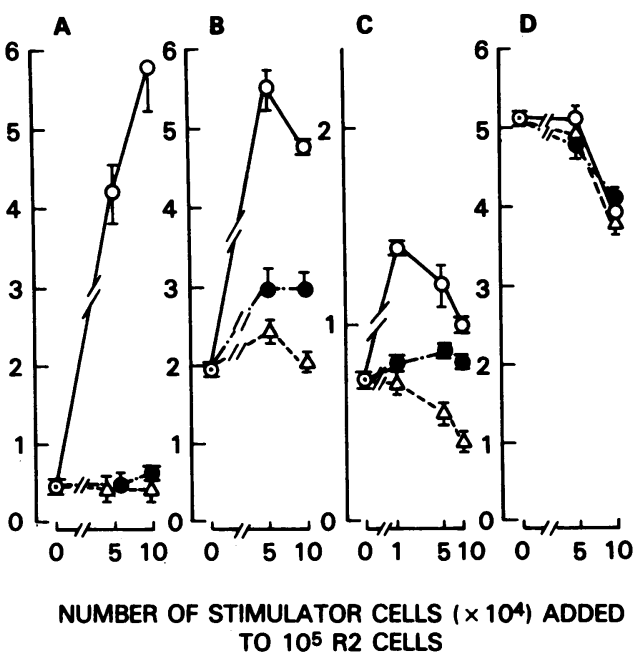

Figure 2. Proliferative response of clone R2 against MJ-tumor cells. Clone $R 2$ cells were cultured in the presence and the absence $(\odot)$ of various numbers of irradiated MJ-tumor cells (O). The HLA-incompatible, HTLV-I-bearing cell line, HUT-102-B2 $(\Delta)$ and autologous EBV-transformed B cells (MJ-B) (•) were used as control stimulators. Cultures were performed in the absence of exogenous IL-2. The irradiated $(12,000 \mathrm{rad})$ stimulator cells did not proliferate when cultured alone (data not shown). Each symbol represents the mean cpm \pm 1 SD of triplicate determinations. The experiments in panels $A-D$ were performed when clone $R 2$ had been in culture for $23,36,52$, and $70 \mathrm{~d}$ after cloning.

regions revealed that the population had at least six integration sites of HTLV-I provirus (Fig. $3 A$, lane $a$ ). From the relative intensity of the Eco RI bands from the MJ-CTL DNA, however, it would appear that not all of the proviruses were present in all the cells. Digestion with Bam HI (which cuts three times in the HTLV-I $\mathrm{I}_{\mathrm{M}}$ provirus and generates a 3.4-kb gag-pol-containing fragment and a 1-kilobase (kb) env-containing internal fragment) gave $3^{\prime}$ junction fragments, a 3.4-kb internal fragment, and a 1$\mathrm{kb}$ internal fragment (Fig. $3 A$, lane $e$ ). Since the $1-\mathrm{kb}$ internal Bam HI band in the MJ-CTL line is relatively intense, it seems that a large fraction of the MJ-CTL population was infected with HTLV-I, and that most of the proviruses did not have a large internal deletion. When the DNA from MJ-tumor cells was digested with Eco RI, multiple integration of HTLV-I proviruses was observed (Fig. $3 B$, lane $i$ ). This pattern is seen commonly in cultured HTLV-I-producing tumor cells (34). In spite of the presence of integrated proviruses, the MJ-CTL line was negative for the HTLV-I gag proteins p19 and p24 as assessed by indirect immunofluorescence. Moreover, electron microscopic studies did not detect HTLV-I virions in the MJ-CTL line (Tralka, T., J. Cossman, and T. Triche, unpublished data). As has been observed in other settings $(17,29)$, it would thus appear that there is some restriction of viral expression in these cells, since a large fraction of the cells in the line seems to be infected with HTLV-I.

When DNA from the cytotoxic clone $\mathrm{K} 5$ was digested with Eco RI and analyzed by Southern blotting with the $\mathrm{pCH}-1$ probe, an indistinct smear was evident (Fig. $3 B$, lane $j$ ). A similar analysis using Bam $\mathrm{HI}$ gave an intense band of $1 \mathrm{~kb}$, as well as an indistinct background smear (Fig. $3 B$, lane $n$ ). These data suggest a large amount of randomly integrated proviral DNA in the $\mathrm{K} 5$ genome. Clone $\mathrm{C} 5$ did not contain any detectable
A
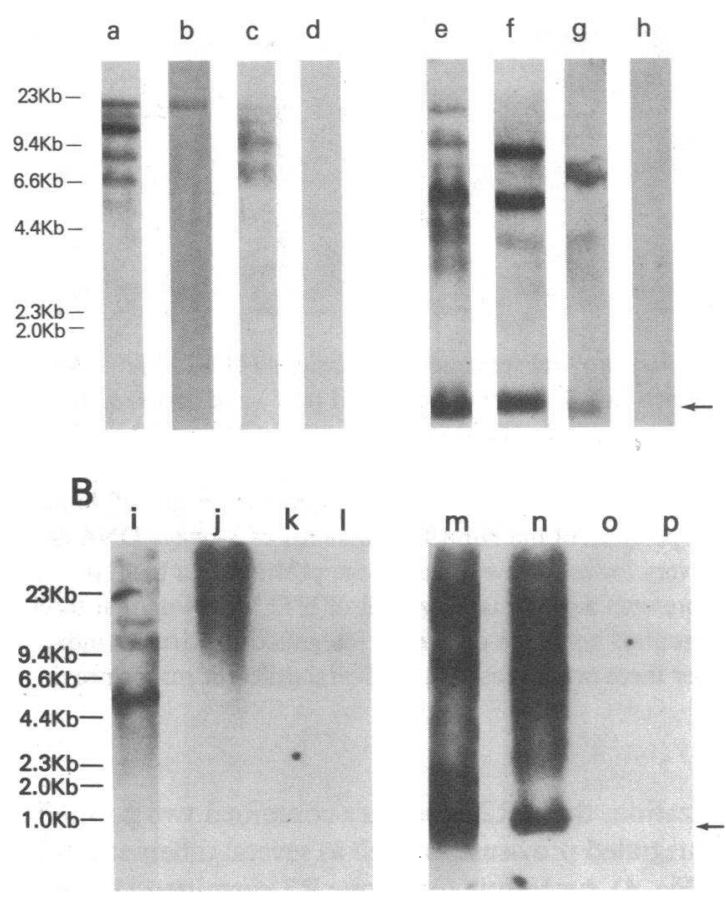

Figure 3. HTLV-I proviral sequences in clones and MJ-CTL population. The indicated DNA was digested with Eco RI (a-d and $\mathrm{i}-\mathrm{l}$ ) and Bam HI (e-h and $\mathrm{m}-\mathrm{p}$ ) and analyzed by Southern blotting using an HTLV-I pol-env-pX (pCH-1) probe. The DNA was from (panel $A$ ) MJ-CTL (day 250 in culture, lanes $a$ and $e$ ), clone K7 (lanes $b$ and $f$ ), clone R2 (lanes $c$ and $g$ ), and PBM from patient M.J. in remission (lanes $d$ and $h$ ); (panel $B$ ) HTLV-I-bearing MJ-tumor cells (lanes $i$ and $m$ ), clone K5 (lanes $j$ and $n$ ), clone C5 (lanes $k$ and $o$ ), and CR-B, an HTLV-I negative, EBV-transformed B cell line from a patient with cutaneous T cell lymphoma (ref. 3) (lanes $l$ and $p$ ). Arrows indicate the position of a band of $1.0 \mathrm{~kb}$, which represents an internal fragment of HTLV-I. Numbers on the left-hand side show the position of the Hind III fragments of $\lambda$-phage DNA as a marker.

provirus (Fig. $3 B$, lanes $k$ and $o$ ). (However, both clones $\mathrm{K} 5$ and $C 5$ remained cytotoxic against HTLV-I-bearing autologous tumor cells and did not grow without exogenous IL-2, as though they were uninfected T cells.) Clone K5, like the starting population, MJ-CTL, was negative for HTLV-I-encoded gag proteins.

In contrast to clones $\mathrm{K} 5$ and $\mathrm{C} 5$, when $\mathrm{K} 7 \mathrm{DNA}$ was digested with Eco RI, the resultant blot showed a single band (Fig. $3 \mathrm{~A}$, lane $b$ ). Digestion with Bam HI gave two internal bands of 1 and $3.4 \mathrm{~kb}$, and two $3^{\prime}$ junction fragments that could be visualized by the pCH-1 probe (Fig. $3 A$, lane $f$ ). This indicates the presence of two integrated HTLV-I proviruses in this population, which cannot be resolved by Eco RI digests. (Previous data with Eco RI had suggested the presence of only a single integrated provirus [29].)

In the DNA of clone R2, there were at least four separate bands observed when digested with Eco RI, indicating that clone R2 contained at least four separate copies of HTLV-I proviruses integrated into the genome (Fig. $3 A$, lane $c$ ). $10-20 \%$ of clone $\mathrm{R} 2$ cells were positive for $\mathrm{p} 19$ and $\mathrm{p} 24 \mathrm{gag}$ proteins and HTLVI-mRNA was readily detected by Northern blot hybridization (Reitz, M. S., Jr., unpublished data). When assessed by Southern 

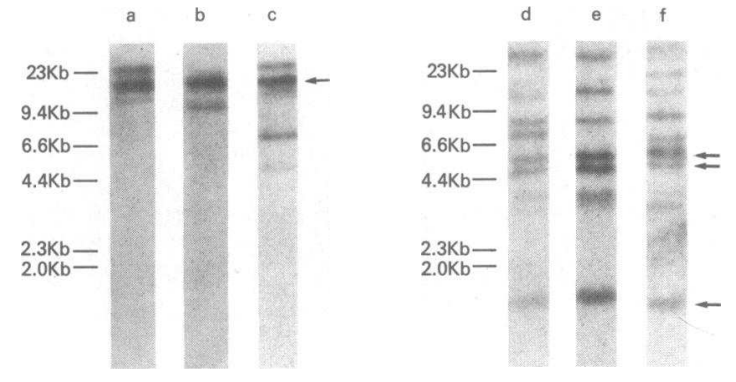

Figure 4. HTLV-I proviral sequences in subclones of R2. The DNA was digested with Eco RI $(a-c)$ and Bam $\mathrm{HI}(d-f)$ and analyzed by Southern blotting using an HTLV-I pol-env-pX $(\mathrm{pCH}-1)$ probe. The DNA was from R2 subclone 1 (lanes $a$ and $d$ ), R2 subclone 2 (lanes $b$ and $e$ ), and R2 subclone 3 (lanes $c$ and $f$ ). Numbers on the left-hand side show the position of the Hind III fragments of $\lambda$-phage DNA as a marker. The very lowest arrow indicates the position of a band of 1.0 $\mathrm{kb}$, which represents an internal fragment of HTLV-I. Note that three subclones contained common dominant integrated proviruses (indicated by upper three arrows) as well as several different minor proviruses.

blot hybridization, three $\mathbf{R} 2$ subclones contained two common dominant integrated proviruses as well as several different minor proviruses (Fig. 4), suggesting that clone R2 permitted viral replication and experienced reinfection in culture. All these data are summarized in Table II.

Status of $T$ cell receptor $\beta$-chain gene in HTLV-I-infected $T$ cell clones. Since the T-cell antigenic receptor $\beta$-chain (TCR- $\beta$ ) gene, located on chromosome $7(35,36)$, undergoes specific rearrangements during the differentiation of $T$ cells (37), we asked whether MJ-CTL and the derived HTLV-I-bearing T cell clones had the same or different rearrangements. As shown in Fig. 5 $A$, when DNA was digested with Eco RI and analyzed by Southern blotting with the TCR- $\beta$ probe, all the clones examined differed in the configuration of the TCR- $\beta$ gene compared to the uncloned starting line, MJ-CTL (Fig. $5 a$, lane $B$ ), which did not appear to have any single predominant pattern of TCR- $\beta$ gene rearrangement. The three R2 subclones (Fig. $5 a$, lanes $C$ $E$ ) had the same rearrangement, showing that the TCR- $\beta$ gene is stable during passage of these cell lines, and verifying their clonality.

Clones K5 and K7 clearly showed the cytotoxic activity against MJ-tumor, WA-tumor, and C145/TK cells (Table I). Interestingly, clones K5 and K7 exhibited the same apparent TCR- $\beta$ gene configuration (Fig. $5 a$, lanes $F$ and $G$; Fig. $5 b$ ). For example, after Eco RI digestion only a single hybridizing band at $4 \mathrm{~kb}$ was seen in clones $\mathrm{K} 5$ and $\mathrm{K} 7$ with loss of the additional bands seen in the germline configuration (Fig. $5 a$, lane $A$ ). This 4-kb fragment contains the $\mathrm{C} \beta 2$ gene segment of the two $\beta$-chain constant region genes ( $C \beta 1$ and $C \beta 2$ ), each capable of rearrangement and expression as mRNA (38). There was no evidence of any rearranged band or of the $11.5-\mathrm{kb}$ germline band that contains the $C \beta 1$ gene segment (Fig. $5 a$, lanes $F$ and $G)$. The apparent absence of the $C \beta 1$ gene in clones $\mathrm{K} 5$ and K7 suggests that it has been deleted from the relevant chromosomes, presumably by variable region gene rearrangement to the $C \beta 2$ gene fragment. These findings suggest that rearrangement of both alleles of the TCR- $\beta$ gene has occurred in clones $\mathrm{K} 5$ and $\mathrm{K} 7$ (assuming no chromosomal loss), and that both rearrangements have utilized the $C \beta 2$ gene segment. When DNA from clones $\mathrm{K} 5$ and $\mathrm{K} 7$ was digested with Hind III and Bam HI, each clone again gave the same pattern on Southern blot analysis, and the bands seen were of a different size from those of the nonrearranged gene (Fig. $5 b$ ); this is consistent with rearrangement of both alleles of the TCR- $\beta$ gene in these clones. Furthermore, when we studied more than 25 different types of $T$ cell clones from several individuals for the rearrangement of TCR- $\beta$ gene, none of the clones except clones K5 and K7 appeared to have the same configuration on Southern blot analyses (data not shown). (The rearranged bands in clones K5 and K7 were not evident in the parental MJ-CTL line [Fig. $5 a$, lane $B$ ],

Table II. Characteristics of Clones Reported

\begin{tabular}{|c|c|c|c|c|c|c|}
\hline \multirow[b]{2}{*}{ Line } & \multirow[b]{2}{*}{ Phenotypes } & \multirow[b]{2}{*}{ Activity against HTLV-I } & \multicolumn{2}{|l|}{ HTLV-I infection } & \multirow[b]{2}{*}{ IL-2 dependence } & \multirow[b]{2}{*}{$\begin{array}{l}\text { Duration of } \\
\text { growth in } \\
\text { culture }\end{array}$} \\
\hline & & & $\begin{array}{l}\text { Number of proviral } \\
\text { copies* }\end{array}$ & $\begin{array}{l}\text { Percent gag } \\
\text { positive } \\
\text { cellsł }\end{array}$ & & \\
\hline Clone C5 & T3, T8 & $\begin{array}{l}\text { Cytotoxicity (maintained } \\
\text { until growth stopped) }\end{array}$ & 0 & ND & IL-2 dependent & $\sim 3 \mathrm{mo}$ \\
\hline Clone K5 & $\mathrm{T} 3, \mathrm{~T} 8$ & $\begin{array}{l}\text { Cytotoxicity (maintained } \\
\text { until growth stopped) }\end{array}$ & Multiple integration & 0 & IL-2 dependent & $\sim 3 \mathrm{mo}$ \\
\hline Clone K7 & $\mathrm{T} 3, \mathrm{~T} 8$ & $\begin{array}{l}\text { Cytotoxicity (lost in } \\
\text { long-term culture) }\end{array}$ & 2 & 0 & $\begin{array}{l}\text { Much less IL-2- } \\
\text { dependent }\end{array}$ & $\geq 2.5 \mathrm{yr}$ \\
\hline Clone R2 & $\mathrm{T} 3, \mathrm{~T} 4$ & $\begin{array}{l}\text { Proliferation (lost in } \\
\text { long-term culture) }\end{array}$ & $\geq 4$ & $10-20$ & $\begin{array}{l}\text { Originally IL-2- } \\
\text { dependent and } \\
\text { later-independent }\end{array}$ & $\geq 2.5 \mathrm{yr}$ \\
\hline MJ-CTL§ & $\begin{array}{c}\mathrm{T} 3, \mathrm{~T} 8(\mathrm{~T} 4 \text { in } \\
\text { small \%) }\end{array}$ & $\begin{array}{l}\text { Cytotoxicity and proliferation } \\
\text { (maintained both until } \\
\text { growth stopped) }\end{array}$ & $\geq 6$ & 0 & IL-2 dependent & $\sim 10$ \\
\hline MJ-tumor§ & T3, T4 & - & Multiple integration & $70-80$ & IL-2 dependent & $\geq 3 \mathrm{yr}$ \\
\hline
\end{tabular}

* Assessed by Southern blot hybridization by using an endonuclease Eco RI and an HTLV-I probe. $¥$ HTLV-I-gag-gene-encoded proteins, p19 and p24, were detected by indirect immune fluorescence assay. Numbers show the percentages of positive cells. § The uncloned MJ-CTL line (tested on day 106 in culture) and MJ-tumor cells are shown for reference. 

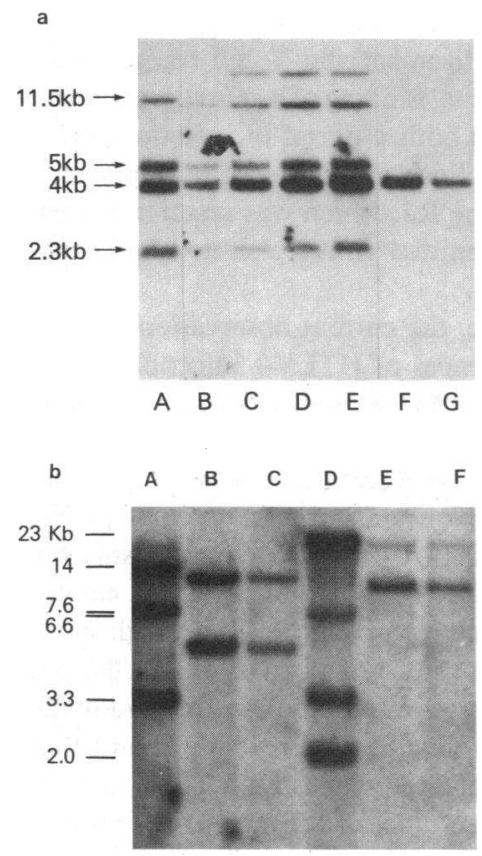

Figure 5. T cell receptor $\beta$ chain configuration in MJCTL and derived clones. The DNA was digested with Eco RI (a), Hind III (b), or Bam HI $(b)$, and subjected to Southern blot analysis using the TCR- $\beta$ chain probe YTJ2 insert, which contains variable and constant region sequences. $(a)$ The DNA was from CR-B, an HTLV-I-negative, EBVtransformed B cell line (ref. 3) (lane $A$ ), MJ-CTL (lane $B), \mathrm{R} 2$ subclone 1 (lane $C$ ), R2 subclone 2 (lane $D$ ), R2 subclone 3 (lane $E$ ), clone K7 (lane $F$ ), and clone K5 (lane $G$ ). Lane $A$ shows the germline configuration of the TCR- $\beta$ chain gene. Two constant region gene segments are present in the non-rearranged gene; the band at $11.5 \mathrm{~kb}$ corresponds to the $C \beta 1$ gene segment and that at $4 \mathrm{~kb}$ to the $C \beta 2$ gene segment (ref. 37). Bands at 5 and $2.3 \mathrm{~kb}$ represent hybridization to variable region gene segment. Lane $B$ shows a similar pattern of bands suggesting that there are no predominant rearrangements within the MJ-CTL population. In lanes $C-E$ an additional band is seen at the top of the figure, indicating rearrangement of the TCR- $\beta$ chain gene. ( $b$ ) The DNA was from CR-B (lanes $A$ and $D$ ), clone $\mathrm{K} 7$ (lanes $B$ and $E$ ) and clone $\mathrm{K} 5$ (lanes $C$ and $F$ ). Lanes $A$ and $D$ show the germline configuration of the TCR- $\beta$ chain gene. Note that clones $\mathrm{K} 5$ and $\mathrm{K} 7$ again gave the same pattern and the bands were of a different size from those of non-rearranged genes in lanes $A$ and $D$.

indicating that the progenitor cell of clones $\mathrm{K} 5$ and $\mathrm{K} 7$ did not constitute a majority of the MJ-CTL population.) Studies on the rearrangement of the T cell receptor $\alpha$-chain gene were performed on the clones $\mathrm{K} 5$ and $\mathrm{K} 7$. Using a T cell receptor $\alpha$ chain gene constant region probe we were unable to detect rearrangement of this gene in DNA from $\mathrm{K} 5$ and $\mathrm{K} 7$, presumably to the long distance between the joining and constant region gene segments. Using full length cDNA probe, however, we noted that at least one fragment hybridizing to the variable region sequence was absent in DNA from $\mathrm{K} 5$ and $\mathrm{K} 7$ but not from other clones derived from the MJ-CTL line (data not shown). This is, at least, consistent with these clones having the same $\mathrm{T}$ cell receptor $\alpha$-chain gene rearrangement. These data suggest that clones $\mathrm{K} 5$ and $\mathrm{K} 7$ arose from the same $\mathrm{T}$ cell. This is noteworthy in view of their differing functional properties following infection by HTLV-I.

Under certain conditions immune $T$ cells lose their antigenspecific reactivity following infection with $\operatorname{HTLV}-\mathrm{I}(17,18,29)$. Clones K7 and R2 also lost their immune reactivity after an extensive time in culture in this study. We then attempted to compare the levels of mRNA for the TCR- $\beta$ gene present in the uncloned functioning MJ-CTL line (Fig. 6, lane .C), clone $\mathrm{K} 7$ (Fig. 6, lane $D$ ) at a time when it no longer responded to antigen, clone K5 (Fig. 6, lane $E$ ), which maintained its function, and clone R2 (Fig. 6, lane $F$ ) at a time when it had lost its reactivity against antigen. The level of TCR- $\beta$ mRNA was similar in all

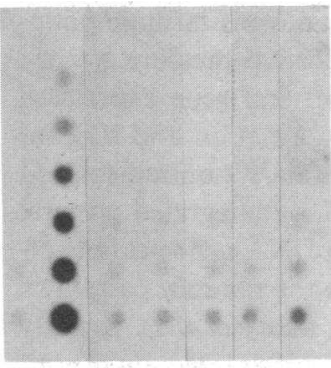

A B C D E F G
Figure 6. T cell receptor $\beta$-chain mRNA levels in MJ-CTL and derived clones. RNA solutions were spotted in vertical rows using twofold serial dilutions. The filter was hybridized with the ${ }^{32} \mathrm{P}$-nick-translated probe YTJ2 insert containing constant and variable regions of the TCR- $\beta$ gene. Each mRNA spotted was quantitated by hybridization with a ${ }^{32}$ P-nick-translated probe pDPO insert for HLA class I antigen (ref. 54). The mRNA was from longer responded to antigen (lane $D$ ), clone $\mathrm{K} 5$ which maintained its function (lane $E$ ), clone $\mathrm{R} 2$ when it no longer showed specific reactivity to antigen (lane $F$ ), and PHA-activated normal T cells (lane $G$ ). Negative and positive controls consist of the mRNA from CR-B, an EBV-transformed B cell line (ref. 3) (lane $A$ ) and CEM, a leukemic T cell line (lane $B$ ), which expresses 10-20-fold more TCR- $\beta$ mRNA than mature $T$ cells (ref. 37), respectively.

four cell lines, although it was marginally lower than that observed in PHA-activated normal T cells (Fig. 6, lane $G$ ). The levels of TCR- $\beta$ mRNA were also similar in K 7 cells, which still maintained their ability to respond to antigen and $K 7$ cells that had lost that ability (data not shown).

It is possible that the loss of cytotoxic activity could be explained by alterations in the expression of the $\alpha$-chain of the T cell receptor. However, when we compared the levels of expression of the T cell receptor $\alpha$-mRNA in various cloned T cells before and after infection by HTLV-I we were unable to detect any appreciable differences (data not shown).

\section{Discussion}

While it has been possible to extensively analyze the molecular biology, serology, and epidemiology of human pathogenic retroviruses $(1-4,39-42)$, a great deal remains to be learned about tumor-specific cellular immune functions in patients who have HTLV-I-associated neoplasms.

In this study, HTLV-I-specific T cell (MJ-CTL) lines were cloned in the presence of infectious virions on four separate occasions and four representative clones were extensively characterized. The differences in functions (activity against HTLVI, IL-2 dependence, and growth duration) are summarized in Table II. The uncloned line MJ-CTL remained functional (the line proliferated in response to and was cytotoxic. against HTLVI-bearing autologous tumor cells) throughoutt the course of these studies, while at least a substantial fraction of cells within the line contained HTLV-I proviruses. This parental line exhibited a pattern of multiple HTLV-I proviral integration into its DNA. Clone K5, one of the cytotoxic clones, contained a large amount of randomly integrated HTLV-I proviruses. This clone remained dependent on IL-2 and stopped its growth within $\sim 3$ mo after cloning, features common to uninfected, IL-2-dependent, normal T cells. Our observations that MJ-CTL and clone K5, both of which contained HTLV-I proviruses, were negative for HTLVI-encoded viral gag proteins and seemed to behave like normal IL-2-dependent $T$ cells would suggest that under certain conditions viral proteins are not expressed in HTLV-I-infected cultured immune $\mathrm{T}$ cells, and therefore an IL-2-independent growth advantage is not conferred on such $T$ cells. It is possible that the cytotoxic $\mathrm{T}$ cells may have destroyed any HTLV-I-infected T 
cells that happened to synthesize viral antigens in these populations, bringing to bear a kind of selective pressure against HTLV-I expression. Such inhibition of viral gene expression may also be related to the lack of transformation and IL-2 independence. The presence in the apparently nontransformed K5 cell line of a large amount of randomly integrated proviral DNA suggests that the presence of viral DNA per se is not sufficient for transformation. We interpret the random pattern to mean that the $\mathrm{K} 5$ cells at the time of analysis were recently infected (which is what is observed shortly after infection of cord blood $T$ cells) and that the presumably relatively rare transformed cells (if any) had not yet undergone clonal expansion. The lack of a dominant pattern of retroviral integration in clone $\mathrm{K} 5$ thus suggests that the number of proviral integration sites that result in $T$ cell transformation is finite, and that none of these was occupied in clone $\mathrm{K} 5$.

Recent advances in characterizing antigen-receptor genes and molecules have shed light on the nature and the mechanism of immune $T$ cell reactivity $(35-38,43-48)$. In this context, our finding in the current study is that all the HTLV-I-infected T cell clones under discussion-without regard to the retained functions-expressed similar levels of mRNA for the TCR- $\beta$ gene. The helper/inducer clone $\mathrm{R} 2$, at a time when it had lost its specific antigen reactivity, and other HTLV-I-infected clones, which retained their function, expressed comparable levels of TCR- $\beta$ mRNA. This finding suggests that the loss of function following HTLV-I infection is not associated with a significant change of expression of TCR- $\beta$ mRNA levels per se. However, since mRNA expression may vary in different $T$ cell clones, it would be necessary to explore the levels of expression of the mRNA in one $T$ cell clone with defined characteristics before and after infection with HTLV-I. In this regard, we have data that a cloned $\mathrm{T}$ cell line, with known antigenic specificities, expresses only slightly lower levels of $\mathrm{T}$ cell receptor gene mRNA following in vitro infection by HTLV-I (49). Another finding that two functionally differing clones (K5 and $\mathrm{K} 7$ ) have the same rearrangement of the TCR- $\beta$ gene (suggesting that they have the same clonal origin) is noteworthy. The proviruses detected in both clones do not seem to have a large internal deletion, since the 1-kb internal Bam $\mathrm{HI}$ bands were relatively intense in DNA from both clones (Fig. $3 A$, lane $f$; and $3 B$, lane $n$ ). Taken together, these observations suggest that under certain conditions the functional consequences of HTLV-I infection in immune T cells might be affected by the pattern of HTLV-I infection (e.g., number of integrated proviruses and/or integration sites).

Clone R2, which has the phenotype of a helper/inducer $T$ cell, is of special interest from at least two perspectives. One perspective from which this clone may be viewed relates to the relationship between cell-mediated immunity to type $\mathrm{C}$ retroviruses and leukemogenesis. There are data suggesting that chronic immunostimulation and the profound general amplification of the immune system resulting from persistent viremia eventually leads to somatic errors, bringing about a neoplastic transformation of proliferating $T$ cells $(50,51)$. Clone $R 2$ can be viewed in the context of the receptor-mediated leukemogenesis theory, which for the most part has been predicated on data from studies of retrovirus-associated lymphomas of rodents (52). The theory proposes that antigen-specific lymphocytes can be a target for infection by an oncogenic retrovirus, a point that has not been fully resolved in animals, but which we believe our current work indicates is the case for human beings. According to this theory, retrovirus-induced lymphomas can be the progeny of normal cells that bear antigen-specific $T$ cell receptors for engaging viral envelope antigens. Binding of a retrovirus to these cells is postulated to provide both a portal of infection and a continuous mitogenic signal. Such events might have played a role in the emergence of clone $R 2$, which was reactive against HTLV-I in proliferation, permitted viral replication and experienced reinfection in culture.

From another perspective, the current observations on the range of functional consequences of HTLV-I infection in immune $\mathrm{T}$ cells might be relevant to the clinical immunosuppression observed by physicians who attend patients with HTLV-Iassociated disorders $(4,9-11,53)$. Recently, we have shown that tetanus-toxoid specific $T$ cell clones may retain antigen-specific reactivity after infection by HTLV-I in vitro, while losing the normal $T$ cell requirement for accessory cells (17). In certain settings, such HTLV-I-infected clones can develop a high spontaneous rate of replication in the absence of IL-2, and the observable antigen-driven proliferative response can then gradually be lost. Moreover, Popovic et al. (18) have recently shown that infection of normal cytotoxic T cell clones by HTLV-I as well as HTLV-II led to a diminution or loss of the cytotoxic function (18). Such loss of function observed in immune $T$ cells following HTLV-I infection could have bearing on the capacity of certain individuals to mount an immune response against HTLV-I, and could also contribute to a generalized immune dysfunction. At this time, a number of functional alterations in HTLV-I-infected $T$ cells remain unexplained. A resolution of these issues will have clinical and therapeutic implications.

\section{Acknowledgments}

The authors would like to thank Dr. Robert C. Gallo for his advice, Dr. Jacqueline Whang-Peng for her helpful discussion, and Dr. Jay Berzofsky and Dr. Robert Yarchoan for a critical review of the manuscript.

\section{References}

1. Poiesz, B. J., F. W. Ruscetti, A. F. Gazdar, P. A. Bunn, J. P. Minna, and R. C. Gallo. 1980. Detection and isolation of type-C retrovirus particles from fresh and cultured lymphocytes of a patient with cutaneous T-cell lymphoma. Proc. Natl. Acad. Sci. USA. 77:7415-7419.

2. Reitz, M. S., B. J. Poiesz, F. W. Ruscetti, and R. C. Gallo. 1981. Characterization and distribution of nucleic acid sequences of a novel type C retrovirus isolated from neoplastic human T lymphocytes. Proc. Natl. Acad. Sci. USA. 78:1887-1891.

3. Gallo, R. C., D. Mann, S. Broder, F. W. Ruscetti, M. Maeda, V. S. Kalyanaraman, M. Robert-Guroff, and M. S. Reitz, Jr. 1982. Human T-cell leukemia-lymphoma virus (HTLV) is in T- but not B-lymphocytes from a patient with cutaneous T-cell lymphoma. Proc. Natl. Acad. Sci. USA. 79:5680-5683.

4. Broder, S., P. A. Bunn, E. S. Jaffe, W. Blattner, R. C. Gallo, T. A. Waldmann, and V. T. DeVita. 1984. T-cell lymphoproliferative syndrome associated with human T-cell leukemia/lymphoma virus. Ann. Intern. Med. 100:543-557.

5. Popovic, M., M. G. Sarngadharan, E. Read, and R. C. Gallo. 1984. Detection, isolation, and continuous production of cytopathic retroviruses (HTLV-III) from patients with AIDS and pre-AIDS. Science (Wash. DC). 224:497-500.

6. Gallo, R. C., S. Z. Salahuddin, M. Popovic, G. M. Shearer, M. Kaplan, B. F. Haynes, T. J. Parker, R. Redfield, J. Oleske, B. Safai, G. White, P. Foster, and P. D. Makham. 1984. Frequent detection and isolation of cytopathic retroviruses (HTLV-III) from patients with AIDS and at risk for AIDS. Science (Wash. DC). 224:500-503. 
7. Barré-Sinoussi, F., J. C. Chermann, F. Rey, M. T. Nugeyre, S. Chamaret, J. Gruest, C. Dauguet, C. Axler-Blin, F. Vézinet-Brun, C. Rouzioux, W. Rosenbaum, and L. Montagnier. 1983. Isolation of a Tlymphotropic retrovirus from a patient at risk for acquired immune deficiency syndrome (AIDS). Science (Wash. DC). 220:868-871.

8. Levy, A. J., A. D. Hoffman, S. M. Kramer, J. A. Landis, J. M. Shimabukuro, and L. S. Oshiro. 1984. Isolation of lymphocytopathic retroviruses from San Francisco patients with AIDS. Science (Wash. DC). 225:840-842.

9. Yodoi, J., K. Takatsuki, and T. Masuda. 1974. Two cases of Tcell chronic leukemia in Japan. N. Engl. J. Med. 290:572.

10. Takatsuki, K., T. Uchiyama, K. Sagawa, and J. Yodoi. 1977. Adult T-cell leukemia in Japan. In Topics in Hematology, Proceedings of the 16th International Congress of Hematology. T. Seno, F. Takaku, and S. Irino, editors. Excerpta Medica-Elsevier/North-Holland, Amsterdam. 73-77.

11. Uchiyama, T., J. Yodoi, K. Sagawa, K. Takatsuki, and H. Uchino. 1977. Adult T-cell leukemia. Clinical and hematologic features of 16 cases. Blood. 50:481-492.

12. Bunn, P. A., Jr., G. P. Schechter, E. Jaffe, D. Blayney, R. C. Young, M. J. Matthews, W. Blattner, S. Broder, M. Robert-Guroff, and R. C. Gallo. 1983. Clinical course of retrovirus-associated adult T-cell lymphoma in the United States. N. Engl. J. Med. 309:257-264.

13. Uchiyama, T., K. Sagawa, K. Takatsuki, and H. Uchino. 1978. Effect of adult T-cell leukemia cells on pokeweed mitogen-induced normal B-cell differentiation. Clin. Immunol. Immunopathol. 10:24-34.

14. Miyoshi, I., I. Kubonishi, S. Yoshimoto, T. Akagi, Y. Ohtsuki, Y. Shiraishi, K. Nagata, and Y. Hinuma. 1981. Type C virus particles in a cord T-cell line derived by cocultivating normal human cord leukocytes and human leukaemic T cells. Nature (Lond.). 294:770-771.

15. Popovic, M., P. S. Sarin, M. Robert-Guroff, V. S. Kalyanaraman, D. Mann, J. Minowada, and R. C. Gallo. 1983. Isolation and transmission of human retrovirus (human T-cell leukemia virus). Science (Wash. DC). 219:856-859.

16. Markham, P. D., S. Z. Salahuddin, B. Macchi, M. Robert-Guroff, and R. C. Gallo. 1984. Transformation of different phenotypic types of human bone marrow T-lymphocytes by HTLV-I. Int. J. Cancer. 33:1317.

17. Mitsuya, H., H.-G. Guo, J. Cossman, M. Megson, M. S. Reitz, Jr., and S. Broder. 1984. Functional properties of antigen-specific T-cells infected by human T-cell leukemia/lymphoma virus (HTLV-I). Science (Wash. DC). 225:1484-1486.

18. Popovic, M., N. Flomenberg, D. J. Volkman, D. Mann, A. S. Fauci, B. Dupont, and R. C. Gallo. 1984. Alterations of T-cell functions by infection with HTLV-I or HTLV-II. Science (Wash. DC). 226:459462.

19. Mitsuya, H., L. A. Matis, M. Megson, P. A. Bunn, C. Murray, D. L. Mann, R. C. Gallo, and S. Broder. 1983. Generation of an HLArestricted cytotoxic $\mathrm{T}$ cell line reactive against cultured tumor cells from a patient infected with human T cell leukemia/lymphoma virus (HTLV). J. Exp. Med. 158:994-999.

20. Mitsuya, H., L. A. Matis, M. Megson, O. J. Cohen, D. L. Mann, R. C. Gallo, and Samuel Broder. 1984. Immune T-cells reactive against human T-cell leukaemia/lymphoma virus. Lancet. i:649-652.

21. Kannagi, M., K. Sugamura, K. Kinoshita, H. Uchino, and Y. Hinuma. 1984. Specific cytolysis of fresh tumor cells by an autologous killer $\mathrm{T}$ cell line derived from an adult $\mathrm{T}$ cell leukemia/lymphoma patient. J. Immunol. 133:1037-1041.

22. Cossman, J., L. M. Neckers, A. Arnold, and S. J. Korsmeyer. 1982. Induction of differentiation in a case of common acute lymphoblastic leukemia. N. Engl. J. Med. 307:1251-1254.

23. Uchiyama, T., S. Broder, and T. A. Waldmann. 1981. A monoclonal antibody (anti-Tac) reactive with activated and functionally mature human T cells. I. Production of anti-Tac monoclonal antibody and distribution of Tac(+) cells. J. Immunol. 126:1393-1397.

24. Leonard, W. J., J. M. Depper, T. Uchiyama, K. A. Smith, T. A Waldmann, and W. C. Green. 1982. A monoclonal antibody, anti-Tac blocks the membrane binding and action of human T-cell growth factor. Nature (Lond.). 300:267-269.

25. Whang-Peng, J., E. C. Lee, H. Sieverts, and I. T. Magrath. 1984. Burkitt's lymphoma in AIDS. Cytogenetic study. Blood. 63:818-822.

26. Robert-Guroff, M., F. W. Ruscetti, L. E. Posner, B. J. Poiesz, and R. C. Gallo. 1981. Detection of the human T cell lymphoma virus p19 in cells of some patients with cutaneous $T$ cell lymphoma and leukemia using a monoclonal antibody. J. Exp. Med. 154:1957-1964.

27. Kalyanaraman, V. S., M. G. Sarngadharan, B. J. Poiesz, F. W. Ruscetti, and R. C. Gallo. 1981. Immunological properties of a type C retrovirus isolated from cultured human T-lymphoma cells and comparison to other mammalian retroviruses. J. Virol. 38:906-915.

28. Trainor, C. D., F. Wong-Staal, and M. S. Reitz, Jr. 1982. Comparative restriction endonuclease maps of proviral DNA of the primate type $C$ simian sarcoma-associated virus and gibbon ape leukemia virus group. J. Virol. 41:298-308.

29. Mitsuya, H., H.-G. Guo, M. Megson, C. Trainor, M. S. Reitz, Jr., and S. Broder. 1984. Transformation and cytopathogenic effect in an immune human T-cell clone infected by HTLV-I. Science (Wash. DC). 223:1293-1296.

30. Manzari, V., F. Wong-Staal, G. Franchini, S. Colombini, E. P. Gelmann, S. Oroszlan, S. Staal, and R. C. Gallo. 1983. Human T-cell leukemia-lymphoma (HTLV): Cloning of integrated defective provirus and flanking cellular sequences. Proc. Natl. Acad. Sci. USA. 80:15741578.

31. Yoshikai, Y., D. Anatoniou, S. P. Clark, Y. Yanagi, R. Songster, P. V. den Elsen, C. Terhorst, and T. W. Mak. 1984. Sequence and expression of transcripts of the human T-cell receptor $\beta$-chain genes. Nature (Lond.). 312:521-524.

32. Clarke, M. F., C. D. Trainor, D. L. Mann, R. C. Gallo, and M. S. Reitz. 1984. Methylation of human T-cell leukemia virus proviral DNA and viral RNA expression in short- and long-term cultures of infected cells. Virology. 135:97-104.

33. Mitsuya, H., and S. Broder. 1985. Human T-cell leukemia/lymphoma viruses (HTLV): A unique family of pathogenic retroviruses. Curr. Topics Microbiol. Immunol. 115:33-51.

34. Wong-Staal, F., B. Hahn, V. Manzari, S. Colombini, G. Franchini, E. P. Gelmann, and R. C. Gallo. 1983. A survey of human leukaemias for sequences of a human retrovirus, HTLV. Nature (Lond.). 302:626628.

35. Caccia, N., M. Kronenberg, D. Saxe, R. Haars, G. A. P. Bruns, J. Goverman, M. Malissen, H. Willard, Y. Yoshikai, M. Simon, L. Hood, and T. W. Mak. 1984. The T cell receptor b chain genes are located on chromosome 6 in mice and chromosome 7 in humans. Cell. 37:10911099.

36. Barker, P. E., F. H. Ruddle, H.-D. Royer, O. Acuto, and E. L. Reinherz. 1984. Chromosomal location of human T-cell receptor gene Tib. Science (Wash. DC). 226:348-349.

37. Yoshikai, Y., Y. Yanagi, N. Suciu-Foca, and T. W. Mak. 1984. Presence of T-cell receptor $m R N A$ in functionally distinct $T$ cells and elevations during intrathymic differentiation. Nature (Lond.). 310:506508.

38. Sims, J. E., A. Tunnacliffe, W. J. Smith, and T. H. Rabbits. 1984. Complexicity of human T-cell antigen receptor b-chain constant- and variable-region genes. Nature (Lond.). 312:541-545.

39. Seiki, M., S. Hattori, Y. Hirayama, and M. Yoshida. 1983. Human adult T-cell leukemia virus: complete nucleotide sequence of the provirus genome integrated in leukemia cell DNA. Proc. Natl. Acad. Sci. USA. 80:3618-3622.

40. Blattner, W. A., and R. C. Gallo. 1985. Human T-cell leukemia/ lymphoma viruses: Clinical and epidemiologic features. Curr. Topics Microbiol. Immunol. 115:67-88.

41. Sodrosky, J. G., C. A. Rosen, and W. A. Haseltine. 1984. Transacting transcriptional activation of the long terminal repeat of human T lymphotropic viruses in infected cells. Science (Wash. DC). 225:378381.

42. Arya, S. K., C. Guo, S. F. Josephs, and F. Wong-Staal. 1985. 
Trans-activating gene of human T-lymphotropic virus type III (HTLVIII). Science (Wash. DC). 229:69-73.

43. Yanagi, Y., Y. Yoshikai, K. Leggett, S. P. Clark, I. Aleksander, and T. W. Mak. 1984. A human T cell-specific cDNA clone encodes a protein having extensive homology to immunoglobulin chains. Nature (Lond.). 308:145-149.

44. Hedrick, S. M., D. I. Cohen, E. A. Nielsen, and M. M. Davis. 1984. Isolation of cDNA clones encoding $T$ cell-specific membrane-associated proteins. Nature (Lond.). 308:149-153.

45. Hedrick, S. M., E. A. Nielsen, J. Kaveler, D. I. Cohen, and M. M. Davis. 1984. Sequence relationships between putative T-cell receptor polypeptides and immunoglobulins. Nature (Lond.). 308:153158.

46. Saito, H., D. M. Kranz, Y. Takagaki, A. C. Hayday, H. N. Eisen, and S. Tonegawa. 1984. A third rearranged and expressed gene in a clone of cytotoxic T lymphocytes. Nature (Lond.). 312:36-40.

47. Romain, P. L., and S. F. Schlossman. 1984. Human T lymphocyte subsets. Functional heterogeneity and surface recognition structures. $J$. Clin. Invest. 74:1559-1565.

48. Yague, J., J. White, C. Coleclough, J. Kappler, E. Palmer, and P. Marrack. 1985. The T-cell receptor: the $\alpha$ and $\beta$ chains define idiotype, and antigen and MHC specificity. Cell. 42:81-87.
49. Jarrett, R. F., H. Mitsuya, D. L. Mann, J. Cossman, S. Broder, and M. S. Reitz. 1986. Configuration and expression of the T cell receptor $\beta$ chain gene in human T-lymphotrophic virus I-infected cells. J. Exp. Med. 163:383-399.

50. Ihle, J. N., and J. C. Lee. 1982. Possible immunological mechanism in C-type viral leukemogenesis in mice. Curr. Topics Microbiol. Immunol. 98:85-101.

51. Lee, J. L., and J. N. Ihle. 1981. Chronic immune stimulation is required for Moloney leukaemia virus-induced lymphomas. Nature (Lond.). 289:407-409.

52. Weissman, I. C., and M. S. McGrath. 1982. Retrovirus lymphomagenesis: Relationship of normal immune receptors to malignant cell proliferation. Curr. Topics Microbiol. Immunol. 98:103-112.

53. Essex, M. E., M. F. McLane, N. Tachibana, D. P. Francis, and T. H. Lee. 1984. Seroepidemiology of human T-cell leukemia virus in relation to immunosuppression and the acquired immunodeficiency syndrome. In Human T-cell Leukemia viruses. R. C. Gallo, M. E. Essex, and L. Gross, editors. Cold Spring Harbor Laboratories, NY. 355-362.

54. Sood, A. S., D. Pereira, and S. M. Weissman. 1981. Isolation and partial nucleotide sequence of a cDNA clone for human histocompatibility antigen HLA-B by use of an oligodeoxynucleotide primer. Proc. Natl. Acad. Sci. USA. 78:616-620. 